\title{
Epizootic process of equine infectious diseases in the Altai Krai
}

[Processo epizoótico de doenças infecciosas equinas no Krai de Altai]

\author{
K.A. Gustokashin, P.I. Baryshnikov, V.V. Razumovskaya,
} G.A. Fedorova, N.A. Novikov

Altai State Agricultural University - Barnaul, Russian Federation

\begin{abstract}
The urgency of the studied problem is due to the need for epizootic monitoring of equine infectious diseases in the Altai Krai and the lack of basic information on the relative and absolute parameters of changes in the epizootic process, scientific, methodological and practical aspects of the assessment of potential risks. The purpose of the article is to study the epizootic process for each nosological form of equine infectious diseases in the Altai Krai based on statistical information over the period from 1964 to 2017. Epizootic method is a leading method of the study of this problem, which allows the identification and discussion of the association of equine infectious diseases with natural and geographical conditions in the Altai Krai. The article presents data on intensive parameters of the epizootic process of equine infectious diseases and their changes with a description of periodic changes in the Altai Krai. The materials of the article provide veterinary and biology specialists with information on the epizootics of various nosological forms of equine infectious diseases in the Altai Krai.
\end{abstract}

Keywords: epizootology, equine infectious diseases, epizootic monitoring, nosological forms of infectious diseases, areas of concern

\section{RESUMO}

A urgência do problema estudado é devida à necessidade de monitoramento epizoótico de doenças infecciosas equinas no Krai de Altai, e a falta de informação básica sobre os parâmetros relativos e absolutos de mudanças no processo epizoótico, e aspectos científicos, metodológicos e práticos da avaliação de potenciais riscos. O propósito do artigo é estudar o processo epizoótico para cada forma nosológica de doenças infecciosas equinas no Krai de Altai, baseado em informação estatística no período de 1964 a 2017. O método epizoótico é o principal método de estudo deste problema, que permite a identificação e discussão da associação entre doenças infecciosas equinas e condições naturais e geográficas do Krai de Altai. Este artigo apresenta dados dos parâmetros intensivos do processo epizoótico de doenças infecciosas bovinas e suas mudanças com uma descrição de mudanças periódicas no Krai de Altai. Os materiais do artigo fornecem informações para especialistas na veterinária e biologia com relação aos epizoóticos de diversas formas nosológicas de doenças infecciosas equinas no Krai de Altai.

Palavras-chave: epizootologia, doenças infecciosas equinas, monitoramento epizoótico, formas nosológicas de doenças infecciosas, áreas de preocupação

\section{INTRODUCTION}

A specific feature of a biogeocenosis is its ability to manifest itself in various functioning modes, which correspond to the differentiated steady states of individual territories (Dzhupina, 2004; Bakulov, 2016). Experimental statistical modelling and planning of multifactorial experiments followed by the decisions on a complex of antiepizootic measures are impossible without a previous formation of epizootic monitoring databases (Makarov et al., 2009; Moiseenko, 2015; Schelkanov et al., 2015). The list of nosological forms, parameters of the 
epizootic process and models of the spread of individual infectious diseases allow the determination of strategic and tactical directions of anti-epizootic activities in the Altai Krai (Guslavsky and Apalkin, 2003; Mingaleyev et al., 2017; Gorokhov et al., 2015).

Use of comparative historical and geographical descriptions of epizootics for the analysis results in the establishment of the patterns in the course of equine infectious diseases and association of the identified biotopes with natural geographical and socio-economic conditions (Gannushkin, 1961; Lvov et al., 2015).

Determination of changes and frequency of epizootics in the areas of interest, as applied to the list of nosological forms, provides a real opportunity for a reliable forecast regarding epizootic situation (Bakulov, 2002). A program analysis of retrospective information is currently an integral part of both fundamental and applied aspects of scientific research in this area of epizootology (Bakulov et al. 2008; Khurana et al., 2016). Higher efficacy of veterinary services in the prevention of infectious diseases is only possible after an adequate assessment of the nosological profile in the epizootic monitoring system (Tarshis and Konstantinov, 1975; Batomunkuev, 2002). The purpose of our study was to investigate the epizootic process of equine infectious diseases and determine its intensive and extensive parameters in the Altai Krai.

\section{MATERIALS AND METHODS}

The studies of the epizootology of equine infectious diseases is based on the epizootic method for studying the epizootic process, analysis of the epizootic reporting and statistics over the period from 1964 to 2017, which were provided by the State Archive of the Altai Krai and the Epizootic Department of the Altai Regional Veterinary Center for the Prevention and Diagnosis of Animal Diseases. Mathematical statistics methods were used (Tarshis and Konstantinov, 1975).

The experimental study site is Federal StateFunded Educational Institution "Altai State Agrarian University", Faculty of Veterinary Medicine, Department of Microbiology,
Epizootology, Parasitology and Veterinary and Sanitary Expertise, districts and farms of the Altai Krai.

The study was conducted in three stages:

- the first stage included a theoretical analysis of existing methods of epizootological studies, scientific and practical literature, thesis on the problem under consideration; the problem, purpose and study methods were highlighted; the plan for collection and analysis of statistical information were prepared.

- at the second stage, the statistical materials of absolute values of the epizootic process in the State Archive of the Altai Krai and the Epizootic Department of the Altai Regional Veterinary Center for the Prevention and Diagnosis of Animal Diseases were processed.

- at the third stage, the elements of the changes in epizootic process intensity for individual diseases were grouped and recorded and their distribution was described.

\section{RESULTS}

The retrospective analysis over the period from 1964 to 2017 in the Altai Krai identified 18 equine infectious diseases: $13(72.2 \%)$ bacterial and 5 $(27.8 \%)$ viral (Table 1). For $9(50.0 \%)$ diseases the source of the pathogen can be domestic animals only, for $8(44.4 \%)$ diseases the source of the pathogen can be domestic and wild animals, in $1(5.6 \%)$ case the disease can be caused by the external environment.

According to the main mechanism of pathogen transmission, the group of infectious diseases with the alimentary transmission was the most numerous $-9(50 \%)$, with respiratory transmission - $3(16.7 \%)$, via integuments - $4(22.2 \%)$ and through carriers - $2(11.2 \%)$. Since 1972, the incidence of diseases transmitted by the alimentary route decreased, and from 1970 to 1985 the number of animals suffering from communicable infections reduced. 
Epizootic process...

Table 1. Nosological profile of equine infectious diseases in the Altai Krai from 1964 to 2017

\begin{tabular}{clccc}
\hline No & \multicolumn{1}{c}{ Nosological form } & $\begin{array}{c}\text { Etiology of the } \\
\text { disease }\end{array}$ & $\begin{array}{c}\text { Source of } \\
\text { pathogen }\end{array}$ & $\begin{array}{c}\text { Transmission } \\
\text { mechanism }\end{array}$ \\
\hline 1 & Rabies & $\mathrm{V}$ & $\mathrm{DW}(\mathrm{Za})$ & $\mathrm{C}$ \\
2 & Botulism & $\mathrm{B}$ & $\mathrm{V}(\mathrm{Za})$ & $\mathrm{A}$ \\
3 & Brucellosis & $\mathrm{B}$ & $\mathrm{DW}(\mathrm{Za})$ & $\mathrm{A}(\mathrm{C})$ \\
4 & Rhinopneumonia & $\mathrm{V}$ & $\mathrm{D}(\mathrm{Z})$ & $\mathrm{C}(\mathrm{A})$ \\
5 & Influenza & $\mathrm{V}$ & $\mathrm{D}(\mathrm{Z})$ & $\mathrm{R}(\mathrm{A})$ \\
6 & Malignant edema & $\mathrm{B}$ & $\mathrm{D}(\mathrm{Z})$ & $\mathrm{C}$ \\
7 & Infectious anemia & $\mathrm{V}$ & $\mathrm{D}(\mathrm{Z})$ & $\mathrm{T}(\mathrm{A})$ \\
8 & Contagious pleuropneumonia & $\mathrm{V}$ & $\mathrm{D}(\mathrm{Z})$ & $\mathrm{R}$ \\
9 & Leptospirosis & $\mathrm{B}$ & $\mathrm{DW}(\mathrm{Za})$ & $\mathrm{A}(\mathrm{C})$ \\
10 & Listeriosis & $\mathrm{B}$ & $\mathrm{DW}(\mathrm{Za})$ & $\mathrm{A}(\mathrm{T}, \mathrm{C})$ \\
11 & Strangles & $\mathrm{B}$ & $\mathrm{D}(\mathrm{Z})$ & $\mathrm{A}(\mathrm{R}, \mathrm{C})$ \\
12 & Necrobacteriosis & $\mathrm{B}$ & $\mathrm{DW}(\mathrm{Za})$ & $\mathrm{A}(\mathrm{C})$ \\
13 & Pasteurellosis & $\mathrm{B}$ & $\mathrm{DW}(\mathrm{Z})$ & $\mathrm{R}(\mathrm{A})$ \\
14 & Salmonellosis & $\mathrm{B}$ & $\mathrm{DW}(\mathrm{Za})$ & $\mathrm{A}(\mathrm{R})$ \\
15 & Anthrax & $\mathrm{B}$ & $\mathrm{DW}(\mathrm{Za})$ & $\mathrm{A}(\mathrm{R}, \mathrm{T}, \mathrm{C})$ \\
16 & Tetanus & $\mathrm{B}$ & $\mathrm{D}(\mathrm{Za})$ & $\mathrm{C}$ \\
17 & Tuberculosis & $\mathrm{B}$ & $\mathrm{D}(\mathrm{Za})$ & $\mathrm{R}(\mathrm{A})$ \\
18 & Enterotoxemia & $\mathrm{B}$ & $\mathrm{D}(\mathrm{Z})$ & $\mathrm{A}$ \\
\hline
\end{tabular}

Notes: $\mathrm{B}$ - bacteriosis, $\mathrm{V}$ - virosis, $\mathrm{D}$ - domestic animals, DW - domestic and wild animals, $\mathrm{Z}$ - zoonosis, Za zooanthroponosis, $\mathrm{A}$ - alimentary, $\mathrm{C}$ - contact, $\mathrm{R}$ - respiratory, $\mathrm{T}$ - transmissible.

For the period of the study, epizootically dangerous diseases with an epizootic course involving a significant number of animals were: bacteriosis (strangles, necrobacteriosis) and virosis (rabies and influenza). At the same time, the most pronounced problem for the incidence of bacteriosis was reported from 1964 to 1994, an epizootic of influenza was observed in 19921993, and rabies was observed during the entire study period. These diseases account for $84.9 \%$ of negative points, $90.4 \%$ of ill and $63.9 \%$ of dead animals. The mortality for all infectious diseases averaged $2.5 \%$, and was $1.7 \%$ for epizootically dangerous diseases (Figure 1.).
Rabies, botulism, brucellosis, equine rhinopneumonitis, equine influenza, malignant edema, infectious anemia, contagious pleuropneumonia, leptospirosis, listeriosis, strangles, necrobacillosis, pasteurellosis, salmonellosis, anthrax, tetanus, tuberculosis were registered in horses over the study period. Most of them are sporadic without spreading, and only rabies, strangles, necrobacteriosis and influenza are the most epizootically dangerous and occur as epizootic diseases with the involvement of a significant number of horses. 


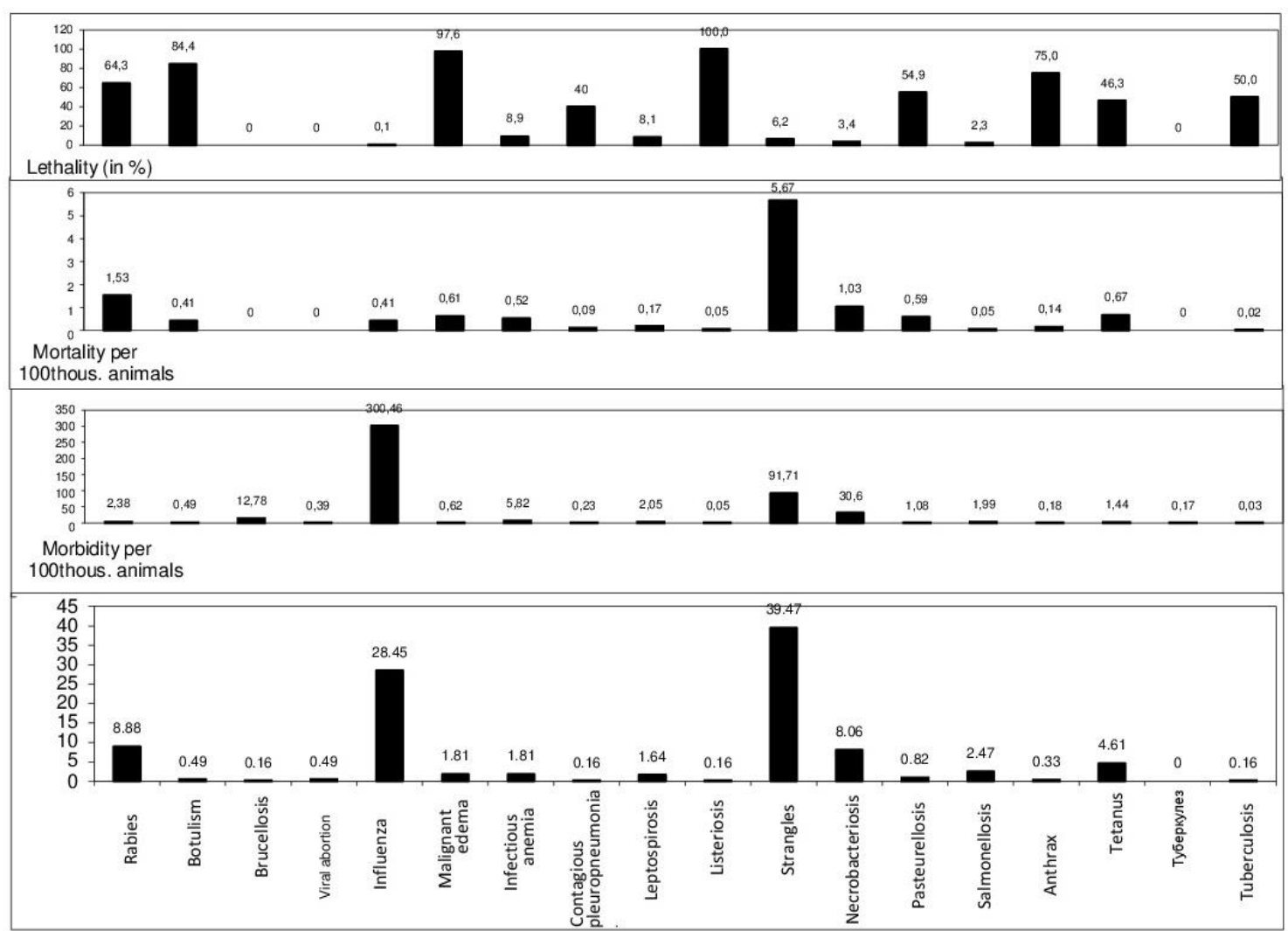

Figure 1. Specific proportion of morbidity, mortality, lethality and the number of negative points for individual nosological forms in the general equine infectious pathology in the Altai Krai from 1964 to 2017

During the monitoring period strangles was recorded in 240 negative points, where 6048 animals fell ill and 374 animals died. Mortality was $6.2 \%$, focality was 25.2 animals per 1 negative point, and morbidity was 97.6 per 100 thousand livestock. The proportion of negative points reached $40.2 \%$, the morbidity rate was $20.5 \%$, and the mortality rate was $49.2 \%$ in the total infectious pathology of horses (Figure 1, Table 2).

The parameters of the epizootic process of equine strangles by year and overtime have significant differences, and no consistent pattern is observed. The significant spread of the disease in the first years of monitoring (1964-1970) and safety from 1999 to 2017 were established. The disease was mostly spread in 1969, when 35 negative points were identified with 990 diseased and 62 dead animals, and the morbidity reached 546.6 animals per 100 thousand livestock. These are the highest rates of the epizootic process for all years of monitoring. The epizootic danger of equine strangles is obvious.

In the steppe area, episootic strangles was reported in 3 districts: Kamensky - from 1969 to 1972, where the morbidity was 110 animals per 10 thousand livestock at the start of the period and decreased to 25; Aleisky - in 1970, 1973 and 1985, the intensity of manifestation decreased overtime and the morbidity was 183,165 and 8 animals per 10 thousand livestock, respectively; Tselinny in 1994, with the morbidity of 241 animals per 10 thousand livestock. 
Epizootic process...

Table 2. Parameters of the epizootic process in equine strangles

\begin{tabular}{|c|c|c|c|c|c|c|c|}
\hline Year & $\begin{array}{c}\text { Negative } \\
\text { points }\end{array}$ & Ill & Died & Morbidity & Mortality & Lethality, \% & Focality \\
\hline 1964 & 26 & 402 & 12 & 217.18 & 6.48 & 2.99 & 15.5 \\
\hline 1965 & 24 & 511 & 22 & 263.27 & 11.33 & 4.31 & 21.3 \\
\hline 1966 & 15 & 369 & 9 & 212.31 & 5.18 & 2.44 & 24.6 \\
\hline 1967 & 15 & 721 & 3 & 391 & 1.63 & 0.42 & 48.1 \\
\hline 1968 & 26 & 636 & 36 & 341.75 & 19.34 & 5.66 & 24.5 \\
\hline 1969 & 40 & 990 & 63 & 546.66 & 34.79 & 6.36 & 24.8 \\
\hline 1970 & 20 & 774 & 9 & 437.04 & 5.08 & 1.16 & 38.7 \\
\hline 1971 & 18 & 346 & 7 & 190.21 & 3.85 & 2.02 & 19.2 \\
\hline 1972 & 4 & 33 & 3 & 17.66 & 1.61 & 9.09 & 8.3 \\
\hline 1973 & 3 & 58 & 10 & 31.66 & 5.46 & 17.24 & 19.3 \\
\hline 1974 & 8 & 309 & 5 & 186.28 & 3.01 & 1.62 & 38.6 \\
\hline 1975 & 2 & 54 & 0 & 31.72 & 0 & 0 & 27 \\
\hline 1976 & 0 & 0 & 0 & 0 & 0 & 0 & 0 \\
\hline 1977 & 2 & 21 & 2 & 13.44 & 1.28 & 9.52 & 10.5 \\
\hline 1978 & 1 & 9 & 0 & 5.25 & 0 & 0 & 9 \\
\hline 1979 & 1 & 4 & 0 & 2.25 & 0 & 0 & 4 \\
\hline 1980 & 1 & 6 & 0 & 3.30 & 0 & 0 & 6 \\
\hline 1981 & 2 & 80 & 0 & 42.17 & 0 & 0 & 40 \\
\hline 1982 & 0 & 0 & 0 & 0 & 0 & 0 & 0 \\
\hline 1983 & 2 & 32 & 2 & 16.94 & 1.06 & 6.25 & 16 \\
\hline 1984 & 6 & 199 & 60 & 146.65 & 44.22 & 30.15 & 33.2 \\
\hline 1985 & 4 & 129 & 11 & 92.14 & 7.86 & 8.53 & 32.3 \\
\hline 1986 & 0 & 0 & 0 & 0 & 0 & 0 & 0 \\
\hline 1987 & 3 & 6 & 6 & 4.03 & 4.03 & 100 & 2 \\
\hline 1988 & 7 & 217 & 89 & 145.64 & 59.73 & 41.01 & 31 \\
\hline 1989 & 3 & 38 & 3 & 25.75 & 2.03 & 7.89 & 12.7 \\
\hline 1990 & 3 & 11 & 11 & 7.43 & 7.43 & 100 & 3.7 \\
\hline 1991 & 1 & 2 & 2 & 1.34 & 1.34 & 100 & 2 \\
\hline 1992 & 0 & 0 & 0 & 0 & 0 & 0 & 0 \\
\hline 1993 & 1 & 26 & 7 & 20.16 & 5.43 & 26.92 & 26 \\
\hline 1994 & 1 & 53 & 2 & 43.19 & 1.63 & 3.77 & 53 \\
\hline 1995-1997 & 0 & 0 & 0 & 0 & 0 & 0 & 0 \\
\hline 1998 & 1 & 12 & 0 & 10.91 & 0 & 0 & 12 \\
\hline $1999-2017$ & 0 & 0 & 0 & 0 & 0 & 0 & 0 \\
\hline
\end{tabular}

In the forest-steppe area, episootic strangles was reported in 8 districts: Loktevsky - in 1969, 1970, the morbidity was 1005 and 525 animals per 10 thousand livestock; Rodinsky - in 1971, 14 horses fell ill and 1 horse died in one negative point with the morbidity of 64 animals per 10 thousand livestock; Zavyalovsky - in 1969, the morbidity was 550 animals per 10 thousand livestock; Mamontovsky - from 1969 to 1971 with a maximum morbidity of 403 animals per 10 thousand livestock in the middle of the epizootics; Pervomaisky - in 1972 one animal fell ill and one animal died in one negative point; Biysky - in 1980 in one negative point 6 animals fell ill in one negative point; Pavlovsky - in 1970 with the morbidity of 40 animals per 10 thousand livestock; Rebrikhinsky - in 1969, 30 animals became ill in one negative point, the morbidity was 120 animals per 10 thousand livestock; Volchikhinsky - in 1970 and 1972 with the incidence of 973 and 10 animals per 10 thousand livestock, respectively.

In the piedmont area, two epizootic episodes were recorded in 1984 and 1993 in the Soloneshensky district, with the morbidity of 11 and 51 animals per 10 thousand livestock, respectively. Necrobacteriosis was not widely spread in the Altai Krai, but in separate years it affects a significant number of horses. During the study period, 49 negative points were revealed, in which 2018 fell ill and 68 animals died. At the same 
time, the morbidity was 32.58 animals per 100 thousand livestock, and the mortality was $3.4 \%$. Necrobacteriosis accounts for $8.21 \%$ of negative points, $6.86 \%$ of morbidity and $8.96 \%$ of mortality in the general equine infectious pathology (Figure 1, Table 3).

Table 3. Parameters of the epizootic process in equine necrobacteriosis

\begin{tabular}{cccccccc}
\hline Year & Negative points & Ill & Died & Morbidity & Mortality & Lethality, \% & Focality \\
\hline 1964 & 9 & 226 & 8 & 122.10 & 4.32 & 3.54 & 25.1 \\
1965 & 3 & 52 & 1 & 26.79 & 0.52 & 1.92 & 17.3 \\
1966 & 1 & 13 & 0 & 7.48 & 0 & 0 & 13 \\
1967 & 2 & 7 & 0 & 3.80 & 0 & 0 & 3.5 \\
1968 & 0 & 0 & 0 & 0 & 0 & 0 & 0 \\
1969 & 5 & 72 & 13 & 39.76 & 7.18 & 18.06 & 14.4 \\
1970 & 2 & 99 & 0 & 55.90 & 0 & 0 & 49.5 \\
1971 & 2 & 38 & 0 & 20.89 & 0 & 0 & 19 \\
1972 & 4 & 9 & 0 & 4.82 & 0 & 0 & 2.25 \\
1973 & 5 & 136 & 4 & 74.24 & 2.18 & 2.94 & 27.2 \\
1974 & 1 & 0 & 0 & 0 & 0 & 0 & 0 \\
$1975-1978$ & 0 & 0 & 0 & 0 & 0 & 0 & 0 \\
1979 & 2 & 44 & 1 & 24.77 & 0.56 & 2.27 & 22 \\
$1980-1983$ & 0 & 0 & 0 & 0 & 0 & 0 & 0 \\
1984 & 4 & 1100 & 0 & 810.61 & 0 & 0 & 275 \\
1985 & 1 & 40 & 10 & 28.57 & 7.14 & 25 & 40 \\
1986 & 0 & 0 & 0 & 0 & 0 & 0 & 0 \\
1987 & 1 & 16 & 0 & 10.74 & 0 & 0 & 16 \\
1988 & 1 & 23 & 0 & 15.44 & 0 & 0 & 23 \\
1989 & 2 & 78 & 10 & 52.85 & 6.78 & 12.82 & 39 \\
1990 & 4 & 65 & 21 & 43.92 & 14.19 & 32.31 & 16.3 \\
$1991-2017$ & 0 & 0 & 0 & 0 & 0 & 0 & 0 \\
\hline
\end{tabular}

In the steppe area, necrobacteriosis was recorded in the Aleisky district in 1985 . In one negative point, 40 animals fell ill and 10 animals died, the morbidity and mortality were 28.6 and 7.14 animals per 10 thousand livestock, respectively. In the forest-steppe area, necrobacteriosis was reported in 2 districts: Kamensky - in 1984 in 2 negative points, 620 animals became ill, the morbidity was 500 animals per 10 thousand livestock; Mamontovsky - in 2 negative points, 480 animals fell ill, the morbidity was 820 animals per 10 thousand livestock.

In the piedmont area, necrobacteriosis was reported in 2 districts: Soloneshensky - in 1964, 124 animals fell ill in 2 negative points, the morbidity was 113 animals per 10 thousand livestock; Smolensky - in the period from 1969 to 1973, the morbidity was 28 animals per 10 thousand livestock in 3 negative points. In 1990, 48 animals fell ill and 10 animals died in one negative point, the morbidity and mortality were 40.3 and 9.2 animals per 10 thousand livestock, respectively. During the study period influenza was reported in 173 negative points, where 19,815 animals fell ill and 27 animals died. The share of negative points in the general infectious pathology reached $28.8 \%$; the morbidity rate was $67.1 \%$, which confirms the epizootic risk of this disease. The morbidity was 145.75 animals per 10 thousand livestock, focality was 136.7. The most incidence of the disease was found in 1992 (Figure 1, Table 4).

In the steppe area, influenza was reported in 2 districts: Aleisky - in 1992, 650 animals fell ill in 3 negative points, the morbidity was 280 animals per 10 thousand livestock; Rubtsovsky - 750 and 97 animals fell ill in 1992 and 1993, respectively, the morbidity was 235 and 30 animals per 10 thousand livestock. In the forest-steppe area, influenza was reported in 3 districts: Tyumentsevsky - in 1992, the morbidity was 1,367 animals per 10 thousand livestock; Mamontovsky - in 1992-1993, 1,050 animals per 10 thousand livestock fell ill; Biysky - in 1992, 560 animals fell ill, the morbidity was 482 animals per 10 thousand livestock. 
Epizootic process...

Table 4. Parameters of the epizootic process in equine influenza

\begin{tabular}{cccccccc}
\hline Year & $\begin{array}{c}\text { Negative } \\
\text { points }\end{array}$ & Ill & Died & Morbidity & Mortality & $\begin{array}{c}\text { Lethali } \\
\text { ty, \% }\end{array}$ & Focality \\
\hline $1964-1991$ & 0 & 0 & 0 & 0 & 0 & 0 & 0 \\
1992 & 143 & 19,545 & 23 & $14,574.95$ & 17.15 & 0.12 & 136.7 \\
1993 & 29 & 228 & 4 & 176.74 & 3.1 & 1.75 & 7.9 \\
$1994-2006$ & 0 & 0 & 0 & 0 & 0 & 0 & 0 \\
2007 & 1 & 42 & 0 & 57.08 & 0 & 0 & 42 \\
$2008-2017$ & 0 & 0 & 0 & 0 & 0 & 0 & 0 \\
\hline
\end{tabular}

In the piedmont area, influenza was reported in 4 districts: Krasnoshchekovskiy - 1,156 horses fell ill and 2 animals died in 3 negative points, the morbidity and mortality were 820 and 7.5 animals per 10 thousand livestock; Kytmanovsky - in 1992, 950 and 4 animals fell ill in 5 negative points, respectively, the morbidity was 741.3 and the mortality was 7.1 animals per 10 thousand livestock; Soloneshensky - 980 fell ill and 4 animals died in 1992-1993, the morbidity and mortality were 756 and 4 animals per 10 thousand livestock, respectively; Smolensky - in 1992, 720 animals fell ill, the morbidity was 453 animals per 10 thousand livestock.

During the monitoring period, rabies was reported in 54 negative points, in which 157 horses fell ill, the average focality was 2.9. Despite sporadic cases of rabies in horses, the need for specific prevention in negative points is obvious (Figure 1, Table 5).

Table 5. Parameters of the epizootic process in equine rabies

\begin{tabular}{cccccccc}
\hline Year & $\begin{array}{c}\text { Negative } \\
\text { points }\end{array}$ & Ill & Died & Morbidity & Mortality & Lethality, \% & Focality \\
\hline $1964-1968$ & 0 & 0 & 0 & 0 & 0 & 0 & 0 \\
1969 & 5 & 13 & 13 & 20 & 20 & 100 & 1.7 \\
1970 & 0 & 0 & 0 & 0 & 0 & 0 & 0 \\
1971 & 0 & 0 & 0 & 0 & 0 & 0 & 0 \\
1972 & 4 & 5 & 5 & 5.1 & 5.1 & 100 & 1.25 \\
1973 & 0 & 0 & 0 & 0 & 0 & 0 & 0 \\
1974 & 0 & 0 & 0 & 0 & 0 & 0 & 0 \\
1975 & 1 & 7 & 7 & 6 & 6 & 100 & 7 \\
1976 & 1 & 4 & 4 & 3 & 3 & 100 & 4 \\
1977 & 2 & 6 & 6 & 8 & 8 & 100 & 5 \\
1978 & & & & & & & \\
1979 & 2 & 8 & 8 & 4.9 & 4.9 & 0 & 4 \\
$1980-1991$ & 0 & 0 & 0 & 0 & 0 & 100 & 15 \\
1992 & 4 & 27 & 18 & 25.6 & 25.6 & 0 & 0 \\
1993 & 0 & 0 & 0 & 0 & 0 & 100 & 6 \\
1994 & 1 & 6 & 6 & 5 & 5 & 100 & 8 \\
1995 & 5 & 18 & 18 & 5.1 & 5.1 & 100 & 3 \\
1996 & 1 & 3 & 3 & 4 & 4 & 100 & 1 \\
1997 & 1 & 1 & 1 & 1.3 & 1.3 & 0 & 0 \\
1998 & 0 & 0 & 0 & 0 & 0 & 0 & 2.9 \\
1999 & 1 & 3 & 3 & 4.2 & 4.2 & 0 & 0 \\
2000 & 0 & 0 & 0 & 0 & 0 & 100 & 0 \\
2001 & 1 & 1 & 1 & 1.2 & 1.2 & 0 & 0 \\
$2002-2017$ & 0 & 0 & 0 & 0 & & 0 & 0 \\
\hline
\end{tabular}

In the steppe area, rabies was reported in 4 districts: Klyuchevskoy - two sporadias in 1972 and 1979, the morbidity was 5 animals per 10 thousand livestock; Pospelikhinsky - in 1977 and 2001 epizootics with the morbidity of 11 and 8 animals per 10 thousand livestock, respectively; 
Slavgorodsky - one animal fell ill and died in each 1969 and 1977, the morbidity was 6 and 8 animals per 10 thousand livestock; Tselinny - sporadias in 1994 and 1995, the morbidity was 5 animals per 10 thousand livestock.

In the forest-steppe area, rabies was reported in 4 districts: Mamontovsky - in 1969, 3 negative points were found, where 6 animals fell ill and died; the morbidity was 20 animals per 10 thousand livestock. The sporadic outbreak was registered in 1996, the morbidity decreased to 4 animals per 10 thousand livestock; Pavlovsky epizootics was observed in 1969 and 1999, the morbidity was 7 and 3 animals per 10 thousand livestock, respectively; Rebrikhinsky - in 1975 the morbidity and mortality were 6 animals per 10 thousand livestock in one negative point; Volchikhinsky - in 1977, the morbidity was 8 animals per 10 thousand livestock.

In the piedmont area, rabies was reported in 3 districts: Kytmanovsky - one animal in each 1997 and 2000; Soloneshensky - in 1992, 12 animals fell ill and 3 died in 1 negative point with a morbidity and mortality of 25.6 and 6 animals per 10 thousand livestock; Charyshsky, sporadias in 1976 and 1977, the morbidity was 3 animals per 10 thousand livestock.

Botulism for the entire monitoring period was reported in 3 negative points, in which 32 horses fell ill. This equine disease has been scarcely reported in the Altai Krai since 1984. This disease is not considered as epizootic. Brucellosis was reported in 1976-77, 1979, 1980-81, 1995 in 10 negative points where 843 horses fell ill. The morbidity was 13.6 animals per 10 thousand livestock, the focality was 17.5 . Rhinopneumonia was reported in 1989 in 3 negative points, where 26 horses fell ill. Cases of death were not registered. The focality was 8.7 . This disease is not considered as epizootic.

During the monitoring period malignant edema was reported in 1964 and from 1984 to 1990. In total, 11 negative points were found, in which 41 horses fell ill and 41 horses died. The highest focality was established in 1984 (13) suggestive of the possible epizootic nature of the manifestation of the disease with $100 \%$ mortality. Since 1991, there have been no cases of this nosological form. Infectious anemia was reported in $1964-65,1985,2004-05$ in 11 negative points, where 384 horses fell ill and 34 horses died. The mortality was $8.9 \%$, and the focality was 34.9 .

Contagious pleuropneumonia was not widely spread in the Altai Krai. 1 negative point was registered in the Pospelikhinsky district of the steppe area in 1980, where 15 horses fell ill and 6 horses died. The mortality was $8.9 \%$, the morbidity was 77 animals per 10 thousand livestock. This disease is not considered as epizootic. Epizootic leptospirosis was manifested in one negative point in 1972. In total, during the monitoring period, 10 negative points were identified, 135 animals fell ill and 11 horses died. The mortality was $8.1 \%$, and the focality was 13.5. Due to the natural focal origin of this disease and its wide spread in other farm animals, the need for preventive measures is obvious.

Listeriosis was registered only in 1964 in one negative point, where 3 horses fell ill and died. In the next years, there were no cases of disease registration, and this disease is not considered as epizootic in horses.

Pasteurellosis was reported in 1989, 1995, and 2008 in 4 negative points, where 70 horses fell ill and 38 horses died. The mortality was $54.3 \%$, and the focality was 17.5. The only case of manifestation of the disease in the epizootic form was established in 1995, when the focality reached 34.5. the epizootic risk of pasteurellosis in horses, as well as among other animals, is possible. Salmonellosis is not widely spread among horses and is manifested mainly in the form of sporadias. During the entire observation period, 14 negative points were revealed, in which 114 and 3 horses fell ill, the average focality was 8.1 , and the maximum focality was 33 ill animals in one negative point. The epizootic risk of this disease exists and the need for the prevention in negative points is obvious.

According to epizootic monitoring tetanus manifested as sporadias. In total, 28 negative points were identified, where 95 horses fell ill and 44 horses died, the mortality was $46.3 \%$, and the focality was 3.3. Since 1993, no cases of the disease have been reported. This disease is not considered as epizootic in horses. Anthrax was reported in 1991 in one negative point, where 11 and 8 animals fell ill, the mortality rate was $72.7 \%$ and in 1996, where 1 horse fell ill and died. Tuberculosis. During the study period, 11 horses fell ill. Since 1979, tuberculosis in horses has not 
been reported. Enterotoxemia. The disease was registered only in 1964 in one negative point, where 2 horses fell ill and one died.

\section{DISCUSSIONS}

Over the period from 1964 to 2017, in the Altai Krai, of all registered nosological forms of equine infectious diseases, the most epizootically significant were virosis - rabies and influenza, and bacterioses - strangles and necrobacillosis. The epizootic process in 14 nosological forms of 18 manifested itself sporadically and did not become widespread. Among infectious pathology of viroses, rabies and influenza played the most important epizootic role, but in 1980 there was a sharp decrease in the incidence of these diseases. As for bacterioses, over the past 40 years, periodic increases in the incidence are followed by decreases, with a general tendency to a decrease. At the same time, the highest incidence of bacterioses was registered from 1964 to 1994, an epizootic of influenza was observed in 1992-1993 and rabies was registered during the entire study period. The proportion of these diseases accounts for $84.9 \%$ of negative points, $90.4 \%$ of the diseased and $63.9 \%$ of dead animals. Mortality caused by all infectious diseases averaged $2.5 \%$. The epizootic risk of strangles due to its wide occurrence in the geographical and retrospective terms is obvious.

Necrobacillosis was most common in the foreststeppe area - Kamensky and Mamontovsky districts, where the incidence was the highest 820 animals per 10 thousand livestock. Equine influenza had massive manifestations in the forest-steppe area, with the maximum incidence in the Tyumentsevsky and Kamensky districts 1367 and 1050 animals per 10 thousand livestock, respectively. Equine rabies was predominantly recorded in the forest-steppe and piedmont areas with the maximum incidence of 20 and 25.6 animals per 10 thousand livestock, respectively. Botulism, brucellosis, rhinopneumonia, malignant edema, infectious anemia, contagious pleuropneumonia, leptospirosis, listeriosis, pasteurellosis, salmonellosis, tetanus, anthrax, tuberculosis and enterotoxemia are not widely spread among horses and occur mostly in the form of sporadic diseases.

The highest epizootic intensity in terms of the nosological profile of equine infectious diseases and the intensity of changes in epizootics was determined for: piedmont area - Charyshsky, Soloneshensky, Krasnoshchekovsky, Kytmanovsky districts; steppe area - Klyuchevskoy, Pospelikhinsky, Slavgorodsky districts; forest-steppe area Volchikhinsky, Mamontovsky, Tyumentsevsky districts. The parameters of the epizootic process summarized in the tables for individual nosological forms make it possible to create a database for the assessment of the epizootic process in the selected areas and stochastic modelling of the epizootic process in the Altai Krai as a whole.

\section{CONCLUSION}

An overall decrease in the levels of morbidity and mortality caused by equine infectious diseases in the Altai Krai has been established. The following nosological forms are considered epizootically dangerous, with the involvement of a significant animal population: bacterioses - strangles and necrobacillosis, and viroses - rabies and influenza. At the same time, the highest incidence of bacterioses was registered from 1964 to 1994, an epizootic of influenza was observed in 1992-1993 and rabies was registered during the entire study period. A noticeable periodicity in the intensity of epizootics is typical for necrobacillosis and strangles. As for the type of the source of the pathogen, it was determined that domestic and wild animals were the cause of trouble in most cases. Infectious diseases of bacterial aetiology with the alimentary route of transmission, the source of the pathogens of which are domestic animals, were predominant. The materials of this article can be useful for epizootology and veterinary specialists of various levels, teachers of veterinary departments and specialists who develop preventive and antiepizootic measures based on extrapolation.

\section{REFERENCES}

BAKULOV, I.A. Epizootology. Ulyanovsk: LLC Copiring, 2002. 45p.

BAKULOV, I.A. Listeria and listeriosis. Ulyanovsk: NIITsMiB, 2016. 327p.

BAKULOV, I.A.; VEDERNIKOV V.A.; WOLF V.T.; GUSLAVSKY, I.I. Basics of general epizootology. Novosibirsk: Nauka, 2008. 264p. 
BATOMUNKUEV, A.S. Epizootology and modeling of the epizootic process of pasteurellosis in the Republic of Buryatia. [Buryatia]: Irkutsk State Agricultural Academy, 2002.

DZHUPINA, S.I. Theory of the epizootic process. Moscow: LLC Veterinary Consultant, 2004. $123 \mathrm{p}$.

GANNUSHKIN, M.S. General epizootology. Moscow: Selkhozgiz, 1961. 264p.

GOROKHOV, V.V.; SAMOILOVSKAYA, N.A.; USPENSKY, A.V.; KLENOVA, I.F. et al. The current epizootic situation and prognosis for the main animal helminth infections in Russia for 2015. Russ. Parasitol. J., v.1, p.41-45, 2015.

GUSLAVSKY, I.I.; APALKIN, V.A. General epizootology with veterinary sanitation. Barnaul: Altai State Agrarian University, 2003. 145p.

KHURANA, S.K.; AMARPAL, A.; MALIK, Y.S.; DHAMA, K. et al. Equine health, infectious diseases and zoonosis (EHIDZ). Didwana: Horizon Publisher India, 2016.
LVOV, D.K.; SHCHELKANOV, M.Y.U.; ALKHOVSKY, S.V.; DERYABIN, P.G. Zoonotic viruses of Northern Eurasia. Taxonomy and ecology. Cambridge: Academic Press, 2015. 452p.

MAKAROV, V.V.; SVYATKOVSKY, A.V.; KUZMIN, V.A.; SUKHAREV, O.I. Epizootological research method. Moscow: Lan, 2009. 224p.

MINGALEYEV, D.N.; SADYKOV, N.I.; RAVILOV, R.KH. Geographical Epizootology. Kazan: Kazan State Academy of Veterinary Medicine named after NE Bauman, 2017. 81p.

MOISEENKO, L.S. Infectious diseases of domestic animals. Diagnostics: treatment and prevention. Kiev: Feniks, 2015.

SCHELKANOV, M.YU; POPOV, A.F.; SIMAKOVA, A.I.; ZENIN I.V. et al. Influenza pathogenesis: pathogen modulation mechanisms of proteins. J. Infectol., v.7, p.31-46, 2015.

TARSHIS, M.G.; KONSTANTINOV, V.M. Mathematical methods in epizootology. Moscow: Kolos, 1975. 176p. 